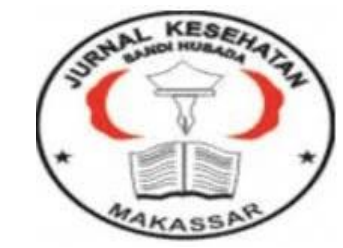

\author{
Jurnal Ilmiah Kesehatan Sandi Husada
}

hhttps://akper-sandikarsa.e-journal.id/JIKSH

Volume 9, Nomor 1, Juni 2020, pp;573-578

p-ISSN: 2354-6093 dan e-ISSN: 2654-4563 DOI: $10.35816 /$ jiskh.v10i2.349

\title{
Kompres Jahe Hangat dapat Menurunkan Intensitas Nyeri pada Pasien Gout Artritis
}

Warm Ginger Compress to Decrease Pain Intensity in Patients with Arthritis Gout

\section{Radhika Radharani}

Fakultas Kedokteran, Universitas Lampung

\section{Artikel info}

Artikel history:

Received; Mei 2020

Revised: Juni 2020

Accepted; Juni2020

\begin{abstract}
Abstrak
Latar Belakang: Gout artritis adalah suata proses peradangan karena terjadinya peradangan di sekitar sendi. Salah satu terapi non-farmakologi pada pasien gout artritis adalah dengan memberikan kompres jahe hangat. Efek panas dari kompres jahe hangat akan menyebabkan vasodilatasi pembuluh darah dan meningkatkan aliran darah ke tubuh dengan rasa sakit yang mengakibatkan penurunan rasa sakit Tujuan : mengetahui lebih lanjut tentang kompres jahe hangat yang dapat menurunkan intensitas nyeri pada pasien gout artritis. Metode : Menggunakan studi literatur dari jurnal baik nasional maupun internasional dengan cara meringkas topic pembahasan dan membandingkan hasil yang disajikan dalam artikel. Hasil : Kompres jahe hangat dapat mengurangi nyeri pada gout artritis. Kompres jahe hangat adalah pengobatan tradisional atau terapi alternatif untuk mengurangi nyeri gout artritis. Jahe mengandung enzim siklooksigenasi yang dapat mengurangi peradangan pada pasien dengan gout artritis, selain itu jahe juga memiliki efek farmakologis berupa sensasi panas dan pedas, di mana panas ini dapat meredakan rasa sakit, kekakuan dan kejang otot atau terjadinya vasodilatasi pembuluh darah, manfaat maksimal akan dicapai dalam waktu 20 menit setelah aplikasi kompres jahe hangat di lokasi nyeri. Kesimpulan : Kompres jahe hangat dapat mengurangi nyeri radang pada pasien gout artritis. Kompres jahe adalah pengobatan tradisional atau terapi alternatif untuk mengurangi nyeri radang sendi gout. Kompres jahe hangat mengandung enzim siklooksigenase yang dapat mengurangi peradangan dan nyeri pada penderita gout artritis
\end{abstract}

\section{Abstract}

Background: Arthritis gout is an inflammation process due to inflammation on cristal sour tendon in tissue around the joint. Non pharmacology action for the patients of Arthritis Gout is warm ginger compress. The effects of heat from a warm ginger compress will cause vasodilation of blood vessels and increases blood flow to the body with pain resulting in a decrease in pain Objective : To know that warm ginger compress can decrease pain intensity in patients with arthritis gout Methods : Using literature studies from national and international journals by summarizing the topic of discussion and comparing the results presented in the article. Results : Warm ginger compresses can reduce pain of arthritis Gout. 
It is a traditional treatment or alternative therapy to reduce pain Gout Arthritis. It contains cyclo-oxygenation enzymes which can reduce inflammation in patients with Arthritis Gout, besides ginger also has a pharmacological effect of burning sensation and spicy, where this heat can relieve pain, stiffness and muscle spasm or the occurrence of vascular vasodilation, maximum benefits will be achieved within 20 minutes after heat application. Conclusion: Warm compresses of ginger can reduce arthritis gout pain. Ginger compress is a traditional treatment or alternative therapy to reduce gouty arthritis pain. Warm ginger compresses contain cyclo oxygenation enzymes which can reduce inflammation in gouty arthritis of sufferers.

Keywords:

Kompres jahe;

Intensitas nyeri;

Gout artritist;
Corsponden author:

Email: radhikaradharani14@gmail.com

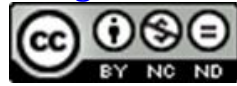

artikel dengan akses terbuka dibawah lisensi BCC BY NC ND-4.0

\section{Pendahuluan}

Asam urat (Gout Arthritis) disebabkan tumpukan asam urat pada sendi-sendi tubuh. Ketika terdapat kelebihan asam urat pada aliran darah dan jumlahnya lebih dari yang dapat dikeluarkan, asam urat tersebut merembes ke dalam jaringan sendi sehingga menyebabkan rasa sakit dan pembengkakan. Rasa nyeri merupakan gejala penyakit Gout yang paling sering (Smeltzer, 2014). Gout Arthritis biasanya paling banyak terdapat pada sendi jempol jari kaki, sendi pergelangan, sendi kaki, sendi lutut dan sendi siku yang dapat menyebabkan nyeri yang sedang meradang karena adanya penumpukan zat purin yang dapat membentuk kristal-kristal yang mengakibatkan nyeri, jika nyeri yang dialami tidak segera ditangani akan mengakibatkan gangguan terhadap aktivitas fisik sehari-hari seperti menurunnya aktivitas fisik (Nahariani, Lismawati, \& Wibowo, 2015). Di Indonesia prevalensi penyakit asam urat pada usia 55-64 tahun sebanyak 45\%, usia 65-74 tahun sebanyak $51,9 \%$, usia $\geq 75$ tahun sebanyak $54,8 \%$. Angka ini menunjukkan bahwa penyakit asam urat nyeri akibat asam urat sudah sangat mengganggu aktivitas masyarakat Indonesia (Riskesdas, 2013). Ada beberapa faktor yang mempengaruhi peningkatan kadar asam urat menjadi tinggi salah satunya adalah perilaku hidup tidak sehat seperti mengkonsumsi makanan mengandung purin tinggi, mengkonsumi alkohol dan obesitas (Zahara, 2013). Serangan gout dicirikan dengan rasa sakit yang menyiksa, dan seringkali berulang. Serangan gout yang berulang juga dapat menyebabkan kerusakan struktural yang berlanjut pada pembentukan tofi, sehingga dapat menimbulkan efek nyeri (Frecklington, dkk, 2011). Adanya kristal asam urat memungkinkan terjadinya interaksi membran fosfolipid dan faktor serum yang berkontribusi terhada reaksi inflamasi dan rasa nyeri (Martillo, Nazzal, \& Crittenden, 2014).

Terapi yang digunakan untuk menurunkan kadar asam urat dan mengurangi rasa nyeri dibagi menjadi 2 yaitu terapi farmakologis dan non farmakologis (Zuriati, 2017). Penanganan asam urat secara farmakologi adalah dengan Obat Anti Inflamasi Non Steroid (OAINS) seperti ibuprofen, naproxen dan allopurinol. Upaya penunjang lain untuk mengatasi nyeri asam urat adalah dengan pengobatan non farmakologis, yaitu dengan memanfaatkan bahan-bahan herbal yang dikenal turun temurun oleh masyarakat dapat berkhasiat menurunkan nyeri, salah satunya adalah: jahe (Wilda \& Panorama, 2020). Pemberian kompres air hangat berfungsi untuk melebarkan pembuluh darah, 
menstimulasi sirkulasi darah, mengurangi kekakuan, dan menghilangkan sensasi rasa sakit. Untuk mendapatkan hasil yang terbaik, terapi kompres hangat dilakukan selama 20 menit dengan 1 kali pemberian dan pengukuran intensitas nyeri dilakukan dari menit ke 15-20 selama tindakan. Pemanfaatan jahe dengan teknik kompres menggunakan air hangat dapat dilakukan selama 15-20 menit dan hal tersebut cukup efektif dalam menghilangkan rasa nyeri (Samsudin, 2016). Kompres Jahe hangat terbukti lebih efektif dalam mengurangi intensitas nyeri dibandingkan kompres dengan hanya menggunakan air hangat saja (Madoni, 2017). Jahe mengandung Olerasin atau Zingerol yang dapat menghambat sintesis prostaglandin, sehingga nyeri reda atau radang berkurang. Prostaglandin itu sendiri adalah suatu senyawa dalam tubuh yang merupakan mediator nyeri dari radang atau inflamasi (Wilda \& Panorama, 2020). Karena itu, diduga bahwa penggunaan kompres hangat jahe juga memiliki efek yang signifikan pula terhadap penurunan nyeri persendian pada kasus artritis gout. Berdasarkan masalah diatas, perlu dilakukan analisis tentang penggunaan jahe dalam menurunkan nyeri pada lansia yang mengalami gout artiritis yang dilakukan melalui literature review.

\section{Metode}

Metode menggunakan studi literatur dari berbagai jurnal nasional maupun internasional. Metode ini digunakan dengan tujuan menambah pemahaman dan pengetahuan tentang topik yang dibahas dengan cara meringkas topik pembahasan. Metode ini memberikan informasi fakta atau analisis baru dari tinjauan literatur yang relevan kemudian membandingkan hasil tersebut dalam artikel. Penulis menggunakan Jurnal yang yang didapatkan melalui google schoolar. Penulis membuka website google schoolar kemudian peneliti menuliskan kata kunci sesuai MESH (Medical Subject Heading) yaitu Ginger dan Gout Arthritis, lalu muncul 74 temuan.

\section{Hasil Dan Pembahasan}

Penyakit degeneratif yang sering dialami oleh lansia salah satunya adalah artritis gout. Artritis gout berhubungan erat dengan gangguan metabolisme purin yang memicu peningkatan kadar asam urat dalam darah (hiperurisemia), yaitu jika kadar asam urat dalam darah lebih dari 7,5 mg/dl. Timbulnya mendadak, pada sendi jari kaki dan sering terjadi pada malam hari (Junaidi, 2013). Prevalensi hiperurisemia asimptomatik pada populasi umum di AS adalah sekitar 2-13\%. Berdasarkan hasil penelitian kesehatan dasar oleh Riskesdas (2013), penyakit sendi saat ini merupakan penyakit terbanyak ketiga $(24,7 \%)$ yang tidak menular setelah stroke (57,9\%) dan hipertensi $(36,8 \%)$, yang meningkat seiring bertambahnya usia. Nyeri adalah suatu sensori subjektif dan pengalaman emosional yang tidak menyenangkan berkaitan dengan kerusakan jaringan yang bersifat aktual atau potensial atau menggambarkan kondisi terjadinya kerusakan. Rasa nyeri merupakan gejala penyakit Gout yang paling sering (Smeltzer, 2014). Dampak nyeri artritis gout yang dapat ditimbulkan berupa menurunnya kualitas hidup penderita karena nyeri yang sangat mengganggu aktivitas sehari-hari (Frecklington, 2011). Nyeri yang berkelanjutan atau tidak ditangani secara secara tepat dan adekuat, memicu respon stres yang berkepanjangan akan memperburuk kualitas kesehatan seseorang (Therkleson, 2010).

Terapi yang digunakan untuk mengurangi rasa nyeri dan peradangan pada pasien gout artritis adalah terapi farmakologis dan non farmakologis. Terapi farmakologis yang dipakai untuk mengurangi peradangan adalah obat anti inflamasi non-steroid (Gliozzi, Malara, Muscoli, \& Mollace, 2016). Terapi non-farmakologis yang dilakukan untuk 
mengurangi rasa nyeri daninflamasi pada pasien gout artritis adalah dengan memberikan stimulasi kulit menggunakan kompres air hangat (Purnamasari, 2015). Tidak hanya terapi dengan menggunakan air hangat, kombinasi air hangat dengan larutan jahe terbukti efektif untuk mengurangi rasa nyeri. Penggunaan jahe dalam bentuk kompres lebih aman daripada penggunaan jahe secara oral. Penggunaan jahe secara oral dan berlebihan dapat menyebabkan gangguan pencernaan seperti diare (Therkleson, 2010).

Di Indonesia terdapat 3 jenis jahe yaitu jahe gajah, jahe merah dan juga jahe emprit. Jahe dapat di tanam dikebun rumah atau hanya dengan menggunakan media tanam dalam polybag atau karung. Penggunaan jahe secara topikal dapat mempengaruhi penyerapan sistemik. Bahan aktif dalam jahe adalah gingerol dan shagaol yang memiliki kelarutan yang sedang dalam air dan minyak sehingga memungkinkan potensi yang baik dalam penyerapan ke dalam kulit (Rahayu H, Rahayu N, \& Sunardi, 2017). Kompres jahe sangat bermanfaat untuk menurunkan nyeri pada pasien Arthritis Gout karena mengandung 6gingerdion,6-gingerol, zingerol yang berfungsi menekan prostaglandin melalui hambatan pada aktivitas COX-2 yang menghambat produksi PGE2 dan leukotrien dan TNF- pada sinoviosit dan sendi manusia (Nahed \& Tavakkoli, 2015).

Kompres jahe merupakan campuran air hangat dan juga parutan jahe yang sudah diparut sehingga akan ada efek panas dan pedas. Efek panas dan pedas dari jahe tersebut dapat menyebabkan terjadinya vasodilatasi pembuluh darah sehingga terjadi peningkatan sirkulasi darah dan menyebabkan penurunan nyeri dengan menyingkirkan produkproduk inflamasi seperti bradikinin, histamine dan prostaglandin yang menimbulkan nyeri. Panas akan merangsang sel saraf menutup sehingga transmisi impuls nyeri ke medulla spinalis dan otak dapat dihambat (Kumar, 2013). Kompres jahe dilakukan dengan cara menempelkan jahe yang telah di sangrai dan di tumbuk terlebih dahulu di area persendian yang mengalami nyeri lalu kemudian dibalut dengan menggunakan kasa gulung, kompres ini dilakukan selama 20 menit (Zuriati, 2017).

Pemberian kompres air hangat saja kurang efektif dalam mengurangi rasa nyeri. Hal tersebut sejalan dengan penelitian yang dilakukan (Izza, 2014) tentang efektifitas pemberian kompres air hangat dan pemberian kompres jahe terhadap penurunan nyeri sendi pada lansia di unit rehabilitasi sosial wening wardoyo ungaran, dari hasil penelitian yang didapatkan bahwa ada perbedaan yang signifikan pemberian terapi kompres air hangat dan kompres jahe terhadap penurunan nyeri sendi lansia di unit rehabilitasi sosial wening wardoyo ungaran, dimana pemberian terapi kompres jahe lebih efektif dibandingkan pemberian terapi kompres air hangat. Hal ini sesuai dengan hasil penelitian Putri tahun 2017 dikemukan bahwa dengan pemberian kompres hangat menggunakan jahe dapat menurunkan skala nyeri pada pasien gout artritis.

\section{Simpulan Dan Saran}

Kompres jahe dengan menggunakan air hangat bisa mengurangi intensitas nyeri pada pasien gout artritis karena jahe mengandung 6-gingerdion, 6-gingerol, zingerol yang berfungsi menekan produk-produk inflamasi seperti histamin, bradikinin dan prostaglandin. Masih perlu dilakukan penelitian lebih lanjut mengenai jenis jahe yang lebih efektif untuk mengurangi rasa nyeri dan inflamasi. 


\section{Daftar Rujukan}

Frecklington, M. J. (2011). Foot Pain, Impairment and Disability in Patients withAcute Gout ; a Prospective Observational Study. Auckland :School ofPodiatry Master of Philosophy AUTUniversity.

Gliozzi, M., Malara, N., Muscoli, S., \& Mollace, V., (2016).The Treatment of Hyperuricemia, International Journal of Cardiology, 213, 23-27.

Izza S.(2014). Perbedaan Efektivitas Pemberian Kompres Air Hangat dan Pemberian Kompres Jahe terhadap Penurunan Nyeri Sendi pada Lansia di Unit Rehabilitasi Sosial Wening Wardoyo Ungaran, Jurnal Keperawatan STIKES Ngudi Waluyo Ungaran.

Junaidi, I. (2013). Rematik dan Asam Urat. Jakarta: Bhuana Ilmu Popule.

Kumar Subodh dkk. (2013). AntiInflammatory Action of Ginger : A Critical Review in Anemia of Inflammation and Its Future Aspects, International Journal of Herbal Medicine, 1(4).

Madoni, A. (2017). Pengaruh Kompres Hangat Memakai Parutan Jahe Terhadap Penurunan Intensitas Nyeri Gout Arthritis Pada Lansia Di Wilayah Kerja Puskesmas Lubuk Begalung. Menara Ilmu Vol. Xii Jilid III No.79.

Martillo, M. A., Nazzal, L., \& Crittenden, D. B., (2014). The Crystallization of monosodium urate, Current Rheumatology Reports, 16(2): 400.

Nahariani, Lismawati \& Wibowo (2015). Hubungan Antara Aktivitas Fisik dengan Intensitas Nyeri Sendi pada lansia di Panti Werdha , 2(2).

Nahed, A., \& Tavakkoli. (2015). Ginger and its effect on inflammatory disease, Departement of Nutrition School of Public Health, 1(4).

Putri, S.Q.D., Rahmayanti, D \& Diani, N. (2017). Pengaruh Pemberian Kompres Jahe Terhadap Intensitas Nyeri Gout Artritis Pada Lansia Di Pstw Budi Sejahtera Kalimantan Selatan. Dunia Keperawatan, 5(2), 90-95.

Purnamasari, S.D.I \& Listyarini, A.D. (2015). Kompres Air Rendaman Jahe Dapat Menurunkan Nyeri Pada Lansia Dengan Asam Urat Di Desa Cengkalsewu Kecamatan Sukolilo Kabupaten Pati. Cendikia Utama Kudus, 1(4),19 - 27.

Rahayu, H. T., Rahayu, N. S., \& Sunardi S. (2017). The Effectiveness of Red Ginger Compress Therapy (Zingiber officinale rosc. var. rubrum) on Elders with Joint Pain. Advances in Health Sciences Research, 2.

Riskesdas. (2013). Badan Penelitian dan Pengembangan Kesehatan. Kementrian Kesehatan RI. http://www.depkes.go.id.

Samsudin, A. R., Kundre, R., \& Onibala, F (2016). Pengaruh Pemberian Kompres hangat Jahe memakai Parutan Jahe Merah (Zingiber Officinale Roscoe Var Rubrum) Terhadap Penurunan Skala Nyeri Oada Penderita Gout Artritis Di desa Tateli Dua Kecamatan Mendolang Kabupaten Minahasa. Jurnal Keperawatan, 4(1).

Smeltzer, S.C.,\& Bare, B. (2014).Text Book Medical Surgical Nursing Brunner-Suddarth. Philadelphia: Lippincot Williams \& Walkins.

Sukandar, dkk. (2009). ISO Farmakoterapi . Jakarta : PT ISFI.

Therkleson, T. (2010), Ginger Compress Therapy for Adults with Osteoarthritis. Journal of Advanced Nursing, 66: 2225-2233. doi:10.1111/j.1365-2648.2010.05355.x.

Wilda \& Panorama. (2020). Warm Compress of Ginger on Changes in Pain Elderlywith Gout Arthritis. Journal of Ners Community, 11(1).

World Health Statistic. (2013). World Health Organization , http://www.who.int/gho/publicatio ns/world_health_statistics/2013/en/. 
Zahara R (2013). Artritis Gout Metakarpal dengan Perilaku Makan Tinggi Purin Diperberat oleh Aktivitas Mekanik Pada Kepala Keluarga dengan Posisi Menggenggam Statis. Medula, 1(3), 67-76.

Zuriati .(2017). Efektivitas Kompres Air Hangat dan Kompres Jahe terhadap Penurunan Nyeri pada Pasien Asam Urat di Puskesmas Lubuk Begalung. Jurnal 